\title{
INFLATION INFLUENCE ABOUT INVESTMENT DECISION
}

\author{
Associate Professor PhD Dorel Berceanu,dorelberceanu@yahoo.com \\ Associate ProfessorPhD Anca Băndoi, anca_bandoi@yahoo.com \\ University of Craiova
}

\begin{abstract}
In this article, we are dealing with an issue very important as regards the investment decision, namely the influence that it has on inflation. Thus, in a brief introduction spotlighted how we have perceived inflation today, what it means and how it manifests itself. An ample space in the paper is dedicated manner of determining the net present value in the presence of inflation, with an emphasis on the link between the real interest rate, the nominal interest rate and the inflation rate. To be convincing in our approach we introduced in the last part of the paper a case study in which we showed how affects inflation on investment decisions, in practical way.
\end{abstract}

Keywords: investment, decision, inflation, cash flow

JEL Codes: $G 31$

\section{Introduction}

The activity of investment in a company is based strategy of economic development set at the level it held and based investment programs or projects. The investment, regardless of which will be developed within a company, the details in order to implement them in more investment projects.

The project investment is defined as a complete and autonomous action involving the achievement of its investment and exploitation of its long life. Therefore, the establishment and use of fixed assets represent the implications of that production on the company, one of the basic elements of the financial mechanism of it. An essential factor of policy continuity and growth of business investment company is contributing to the construction or purchase of assets of production and marketing. Realization of investments requires significant funding needs, leading to impairment of long-term. Therefore, the efficiency of investment projects should be compared with the yield on the investment capital. Given the risk embedded, the decision of investment is a bet on the future of the company.

Investment decision is a very difficult for leaders of all firms. By its very nature, the decision affects the investment a company a long time horizon, if not forever.

In the idea of adopting a investment decision we can use simple criteria or criteria based on discounting. Of the latter category, net present value criterion (NPV) is most often used, since the objective answer to maximize the value of the company called by theory of modern finance.

Results from the application of net present value criterion are, however, different depending on the action or not inflation.

Inflation is a real fact of today which can not be ignored. Even the most developed states have an inflation of several percent, which, as claims Keynes, it is sometimes beneficial for the economy, as the "oil" to "whitewash" the mechanisms and promote economic growth. In an economy with a growth dynamic changes taking place in prices constantly. Organized markets for securities and other goods are normal for prices to change from one transaction to another. Sometimes, the price of a good or service may be a trend upwards or downwards for a period of months or years. However, that price changes are the result of the change request or offer for goods and services does not imply, necessarily, some change in the general level of prices. Increasing the price of goods or services may be offset by the decrease of others, so that the average price may 
remain more or less constant. A change in the average level of prices is if there is a stleig tendency for more prices to move up or down.

It can thus appreciate that inflation represents the accelerated growth, and the general level of prices, matched by increased money, low purchasing power of money and depreciation under the influence of economic, monetary, social, domestic and foreign policies.

Although the idea of a medium level of price is a useful tool, it is important to be aware of its limits. Statisticians to build price index must decide what goods are included in the index and the share allocated to each. An index used frequently, the consumer price index. However, most companies have revenue and expenditure whose components are not closely related to the average price of consumer goods. In these circumstances, careful consideration prices of goods and services become critical when it is necessary to a decision. In capital budgeting, a manager must take into account not only the possible effects of inflation but also the effect of long-term trends in the prices of its products and other major expenses. This is very important because the prices of most of the goods and services purchased by the company are not directly included in the price indices used currently.

\section{The determination of the net present value taking into account the effects of inflation}

In estimating of cash flows, it is important that companies take into account the anticipated inflation. Often, there is a tendency to assume that price levels remain unchanged over the life of the project. Frequently, this is done in ignorance, the simplistic, cash flows can be estimated on the basis of existing prices.

The analysis of investment projects involving at least two distinct steps:

- first, costs and revenues must be described in the same way;

- second, the costs and revenues must be assessed taking into account the goals and objectives decision.

In each of these steps, decision has to choose between using either nominal cash flows or real cash flows.

Even if capital budgeting can be made using either real cash flows or real cash flows, lies in our ability to estimate the necessary inputs, the costs and benefits of the investment project. If costs and revenues are stleigly influenced by the market while the costs are made or produced revenue estimates in real terms may be more accurate than estimates in nominal terms. If, however, the costs and revenues are based on contractual relationships that include a fixed price long-term forecasts in nominal terms can be more precise.

To convert the nominal values in real, nominal values for a given period are divided by the price indices of that period. Point out that a relative price index is the ratio between the two price indices. The value of the numerator is the price index for the year of cash flows. The denominator is the index price of the base.

Hence, cash flows for a project can be described in real terms or in nominal terms. The value of the asset will not be affected if it is analyzed in real terms or in nominal terms as long as it is used to discount a rate appropriate in each case. Thus, with nominal cash flows we will use nominal rate and with real cash flows we will used the real rate. Violating this rule, apparently simple, is a frequent source of errors in assessing the project.

The link between the real interest rate, the nominal interest rate and inflation rate is determined by the relationship of Fisher:

$$
\mathrm{Rr}=\frac{\mathrm{Rn}-\mathrm{Ri}}{1+\mathrm{Ri}}
$$

or: 


$$
\mathrm{Rn}=\mathrm{Ri}+\mathrm{Rr}(1+\mathrm{Ri})
$$

where:

$\mathrm{Rr}=$ real interest rate;

$\mathrm{Rn}=$ nominal interest rate;

$\mathrm{Ri}=$ annual rate of inflation.

Without tax, nominal rate of discounting will reflect expected future rate of inflation, so that changes in expected inflation does not change the expected real rate of interest. In general, investors are taxed will lower income after tax, compared with those who are not taxed. However, there is interaction between the effects of inflation and taxation.

Thus, assume that an investor wants to consider an investment project through the NPV and wonders what most suggestive discounted rate is. Considering the nominal interest rate $\mathrm{Rn}$, if the investor is exempt from tax, real rate of interest can be obtained by applying the relationship (1). The suggestive nominal income for an investor is taxed at higher nominal disposable income after tax. An investor taxed will achieve an income at a nominal rate $\operatorname{Rn}(1-\mathrm{T})$, where $\mathrm{T}$ is the rate of income tax. The suggestive real income after tax depends on the rate of income tax. Note $\operatorname{Rr}(\mathrm{T})$ to emphasize that its value depends on T. The real rate after tax will be:

$$
\operatorname{Rr}(\mathrm{T})=\frac{\operatorname{Rn} \cdot(1-\mathrm{T})-\mathrm{Ri}}{1+\mathrm{Ri}}
$$

In the absence of inflation, $\mathrm{Ri}=0$ and thus: $\operatorname{Rr}(\mathrm{T})=\mathrm{Rn} \cdot(1-\mathrm{T})$

We believe that the investor has the opportunity to invest in assets without risk, exempt from tax at a rate $\operatorname{Re}$. If $\operatorname{Re}$ is greater than $\operatorname{Rn}(1-\mathrm{T})$, when $\operatorname{Re}$ is the opportunity cost of funds actually invested, and we have:

$$
\operatorname{Rr}(\mathrm{T})=\frac{\mathrm{Re}-\mathrm{Ri}}{1+\mathrm{Ri}}
$$

In general, for an investor who expects a rate of annual inflation $\mathrm{Ri}$ and a rate tax $\mathrm{T}$, the actual interest rate after tax is:

$$
\operatorname{Rr}(\mathrm{T})=\frac{\operatorname{Max}(\mathrm{Rn}-\mathrm{Ri}-\mathrm{Rn} \cdot \mathrm{T} ; \mathrm{Re}-\mathrm{Ri})}{1+\mathrm{Ri}}
$$

It notes that there are extreme case in which a positive rate of inflation, the actual rate taxation of an investor taxed to become negative, even if the nominal rate before tax is positive.

Equations above are used to estimate the real effective rate of interest for an investor given the rate of income tax, the nominal interest rate and expected rate of inflation. It is noted that real interest rates vary depending on the rate of income tax. It is also very useful to be able to do a projection of how that changes the actual interest rates if the inflation rate changes. So, in the presence of expected inflation, the nominal interest rate can be thought as having two components: a real and an adjustment for inflation.

Since the investment decision is based on anticipated future cash flows, anticipated rate of inflation will be reflected in the expected profitability of the project or the cost related to capital project. 
Market data used in estimating the current cost of capital will include a premium for anticipated inflation. But as long as the market include an adjustment for inflation in discounted factor, cash flow is estimated by the company used in the analysis of the capital budget may not include an element to reflect future inflation. Given that the cost of capital already includes anticipated inflation, decision may be used to correct in relation to inflation:

- be adding an inflation estimated at cash-flows in numerator;

- numerator is the expression without the inclusion of an adjustment for inflation and move a inflationary factor from the market rate in the denominator.

It is more natural to use the market informations and, explicitly, to incorporate estimates of the inflation rate anticipated in the cash-flows to the numerator. But on the other hand, the problem is difficult to estimate the anticipated rate of inflation.

Demonstrated that as long as inflationary factors are taken into account both the numerator and denominator to the same extent, the effect is null. Thus, when inflation is anticipated duly reflected both the estimates of cash flow from the numerator and the expected profitability (required) income from the market in the denominator, the resulting net present value will be calculated both in real terms as and nominal, resulting in net present value of the resulting estimate will be independent of inflation.

However, the anticipated effect of inflation on the expected rate of income may be different than the estimated cash flows. Indeed, net cash-flow components - the cash inflow and cash outflow - may be affected in varying degrees by the anticipated inflation. The effect of inflation on anticipated cash inflow and the cash outflow design will be different depending on the nature of the project. In some cases, cash inflows, the throught price increases will increase faster than cash outflows; in other cases, it will happen exactly the opposite. No matter, but how they are influenced by inflation, the two components of the cash flow, but it is important that it be included in estimates of cash flows design. The nature of this case more complex is reflected by the following equation:

$$
\mathrm{NPV}_{\text {with inf lation }}=\sum_{\mathrm{t}=1}^{\mathrm{n}} \frac{\left[\mathrm{IF}_{\mathrm{t}} \cdot\left(1+\mathrm{Ri}_{\mathrm{i}}\right)^{\mathrm{t}}-\mathrm{OF}_{\mathrm{t}} \cdot\left(1+\mathrm{Ri}_{0}\right)^{\mathrm{t}}\right] \cdot(1-\mathrm{T})+\mathrm{A} \cdot \mathrm{T}}{(1+\mathrm{a})^{\mathrm{t}}}-\mathrm{I}
$$

where:

$\mathrm{IF}_{\mathrm{t}} \quad=$ cash inflow at the " $\mathrm{t}$ " moment;

$\mathrm{OF}_{\mathrm{t}} \quad=$ cash outflow at the " $\mathrm{t} "$ moment;

$\mathrm{Ri}_{\mathrm{i}} \quad$ = inflation rate of cash inflows;

$\mathrm{Ri}_{\mathrm{o}} \quad$ = inflation rate of cash outflows;

Right parenthesis represents gross operating surplus, the difference between operating income and operating expenses without depreciation.

It is also noteworthy that depreciation can be constant in nominal sum, but the tax savings from depreciation may decrease in real terms.

In general, if we do not take into account the effects of inflation can make an wrong analysis of capital budgeting is clear that the results are more accurate by taking into account the effects of inflation.

\section{Inflation influence about investment decision in practice}

To argue the practice outlined above, consider the following for an investment project: $\mathrm{I}=$ 100,000 lei; anticipated cash inflows: 53,000 lei; anticipated cash outflows: 20,000 lei; $\mathrm{Ri}_{\mathrm{i}}=6 \%$; $\mathrm{Ri}_{\mathrm{o}}=7 \%, \mathrm{Rr}=9 \%, \mathrm{n}=5$ ani; $\mathrm{T}:$ a) $16 \%$ b) $25 \%$ c) $50 \%$.

The issue of determining NPV in the absence and presence of inflation.

According to Fisher's relationship: 


$$
\begin{aligned}
& \mathrm{Rn}=\mathrm{Ri}+\mathrm{Rr}(1+\mathrm{Ri}) \\
& \mathrm{Rn}=0,06+0,09(1+0,06)=0,1554=15,54 \%
\end{aligned}
$$

a) $\mathrm{T}=16 \%$

b)

In table 1 are expected cash-flows without the inflation rate for a tax rate of $16 \%$.

Table no.1

Expected net cash flows without inflation $(T=16 \%)$

\begin{tabular}{|l|r|r|r|r|r|}
\hline \multicolumn{1}{|c|}{ Indicators (lei) } & \multicolumn{1}{c|}{ Year 1 } & \multicolumn{1}{c|}{ Year 2 } & Year 3 & \multicolumn{1}{c|}{ Year 4 } & \multicolumn{1}{c|}{ Year 5 } \\
\hline Anticipated cash inflows & 53.000 & 53.000 & 53.000 & 53.000 & 53.000 \\
\hline Anticipated cash outflows & 20.000 & 20.000 & 20.000 & 20.000 & 20.000 \\
\hline Gross operating surplus & 33.000 & 33.000 & 33.000 & 33.000 & 33.000 \\
\hline Income tax & 5.280 & 5.280 & 5.280 & 5.280 & 5.280 \\
\hline Net operating surplus & 27.720 & 27.720 & 27.720 & 27.720 & 27.720 \\
\hline Tax savings from depreciation (T·A) & 3.200 & 3.200 & 3.200 & 3.200 & 3.200 \\
\hline Anticipated net cash flows & 30.920 & 30.920 & 30.920 & 30.920 & 30.920 \\
\hline
\end{tabular}

Depreciation $\left(\mathrm{A}_{\mathrm{i}}\right)=\frac{100.000}{5}=20.000$ lei, $\mathrm{i}=\overline{1,5}$

$\mathrm{NPV}_{\text {without inf lation }}=\sum_{\mathrm{i}=1}^{5} \frac{30.920}{(1+0,09)^{\mathrm{i}}}-100.000=30.920 \cdot 3,8897-100.000=120.269,52-100.000=20.269,52$ le i> 0 and the project is accepted.

In table 2 the estimates of anticipated net cash flows include the effects of inflation. Cash inflows are subject to an inflation rate of $6 \%$, while cash outflows are subject to an inflation rate of $7 \%$.

Table no. 2

Expected net cash flows taking into account the effects of inflation $(T=16 \%)$

\begin{tabular}{|l|r|r|r|r|r|}
\hline \multicolumn{1}{|c|}{ Indicators (lei) } & \multicolumn{1}{c|}{ Year 1 } & \multicolumn{1}{c|}{ Year 2 } & \multicolumn{1}{c|}{ Year 3 } & \multicolumn{1}{c|}{ Year 4 } & \multicolumn{1}{c|}{ Year 5 } \\
\hline Anticipated cash inflows & 56.180 & 59.551 & 63.124 & 66.912 & 70.927 \\
\hline Anticipated cash outflows & 21.400 & 22.898 & 24.501 & 26.216 & 28.051 \\
\hline Gross operating surplus & 34.780 & 36.653 & 38.623 & 40.696 & 42.876 \\
\hline Income tax & $5.564,80$ & $5.864,48$ & $6.179,68$ & $6.511,36$ & $6.860,16$ \\
\hline Net operating surplus & $29.215,20$ & $30.788,52$ & $32.443,32$ & 34184,64 & $36.015,84$ \\
\hline $\begin{array}{l}\text { Tax savings from } \\
\text { depreciation (T·A) }\end{array}$ & 3.200 & 3.200 & 3.200 & 3.200 & 3.200 \\
\hline Anticipated net cash flows & $32.415,20$ & $33.978,52$ & $35.643,32$ & 37384,64 & $39.215,84$ \\
\hline
\end{tabular}

The expected rate of income, which is also the discounted rate is $15.54 \%$, determined earlier, reflecting an inflation rate of $6 \%$.

NPV calculation is the following: 
$\mathrm{NPV}_{\text {with inflation }}=\frac{32 \cdot 415,20}{1+0,1554}+\frac{33 \cdot 978,52}{(1+0,1554)^{2}}+\frac{35 \cdot 643,32}{(1+0,1554)^{3}}+\frac{37 \cdot 384,64}{(1+0,1554)^{4}}+\frac{39 \cdot 215,84}{(1+0,1554)^{5}}-100.000=$ $=32.415,20 \cdot 0,865+33.978,52 \cdot 0,748+35.643,32 \cdot 0,647+37.384,64 \cdot 0,559+39.215,84 \cdot 0,484-$ $-100.000=28.039,148+25.415,932+23.061,228+20.898,013+18.980,466-100.000=$ $=116.394,787-100.000=16.394,787$ lei

So, $\mathrm{NPV}_{\text {with inf lation }}>0$ and the project is accepted.

It notes, however, that under the influence of inflation, NPV is lower than in the absence thereof.

b) $\mathbf{T}=\mathbf{2 5 \%}$

In Table 3. are expected cash-flows without the inflation rate for a tax rate of $25 \%$.

Expected net cash flows without inflation ( $T=25 \%)$

\begin{tabular}{|l|r|r|r|r|r|}
\hline \multicolumn{1}{|c|}{ Indicators (lei) } & \multicolumn{1}{c|}{ Year 1 } & \multicolumn{1}{c|}{ Year 2 } & Year 3 & \multicolumn{1}{c|}{ Year 4 } & \multicolumn{1}{c|}{ Year 5 } \\
\hline Anticipated cash inflows & 53.000 & 53.000 & 53.000 & 53.000 & 53.000 \\
\hline Anticipated cash outflows & 20.000 & 20.000 & 20.000 & 20.000 & 20.000 \\
\hline Gross operating surplus & 33.000 & 33.000 & 33.000 & 33.000 & 33.000 \\
\hline Income tax & 8.250 & 8.250 & 8.250 & 8.250 & 8.250 \\
\hline Net operating surplus & 24.750 & 24.750 & 24.750 & 24.750 & 24.750 \\
\hline Tax savings from depreciation (T.A) & 5.000 & 5.000 & 5.000 & 5.000 & 5.000 \\
\hline Anticipated net cash flows & 29.750 & 29.750 & 29.750 & 29.750 & 29.750 \\
\hline
\end{tabular}

Depreciation $\left(\mathrm{A}_{\mathrm{i}}\right)=\frac{100.000}{5}=20.000$ lei, $\mathrm{i}=\overline{1,5}$

$\mathrm{NPV}_{\text {without }}$ inf lation $=\sum_{\mathrm{i}=1}^{5} \frac{29.750}{(1+0,09)^{\mathrm{i}}}-100.000=29.750 \cdot 3,8897-100.000=115.718,5-100.000=15.718,5$ lei $>$

0 and the project is accepted.

In Table 4, the estimates of anticipated net cash flows include the effects of inflation. Cash inflows are subject to an inflation rate of $6 \%$, while cash outflows are subject to an inflation rate of $7 \%$.

Table no. 4

Expected net cash flows taking into account the effects of inflation $(T=25 \%)$

\begin{tabular}{|l|c|c|c|c|c|}
\hline \multicolumn{1}{|c|}{ Indicators (lei) } & Year 1 & Year 2 & Year 3 & Year 4 & Year 5 \\
\hline Anticipated cash inflows & 56.180 & 59.551 & 63.124 & 66.912 & 70.927 \\
\hline Anticipated cash outflows & 21.400 & 22.898 & 24.501 & 26.216 & 28.051 \\
\hline Gross operating surplus & 34.780 & 36.653 & 38.623 & 40.696 & 42.876 \\
\hline Income tax & 8.695 & 9.163 & 9.656 & 10.174 & 10.719 \\
\hline Net operating surplus & 26.085 & 27.490 & 28.967 & 30.522 & 32.157 \\
\hline $\begin{array}{l}\text { Tax savings from } \\
\text { depreciation (T·A) }\end{array}$ & 5.000 & 5.000 & 5.000 & 5.000 & 5.000 \\
\hline Anticipated net cash flows & 31.085 & 32.490 & 33.967 & 35.522 & 37.157 \\
\hline
\end{tabular}


The expected rate of income, which is also the discounted rate is $15.54 \%$, determined earlier, reflecting an inflation rate of $6 \%$.

NPV calculation is the following:

$\mathrm{NPV}_{\text {with inflation }}=\frac{31.085}{1+0,1554}+\frac{32.490}{(1+0,1554)^{2}}+\frac{33.967}{(1+0,1554)^{3}}+\frac{35.522}{(1+0,1554)^{4}}+\frac{37.157}{(1+0,1554)^{5}}-100.000=$

$=31.085 \cdot 0,865+32.490 \cdot 0,748+33.967 \cdot 0,647+35.522 \cdot 0,559+37.157 \cdot 0,484=$

$=26.889+24.303+21.977++19.857+17.984=111.010-100.000=11.010$ lei

So, $\mathrm{NPV}_{\text {with inflation }}>0$ and the project is accepted.

c) $\mathbf{T}=\mathbf{5 0 \%}$

Furthermore, the analysis will be carried out starting from the same date, the only distinction being the rate of income tax of $50 \%$.

Table no. 5

Expected net cash flows without inflation $(T=50 \%)$

\begin{tabular}{|l|c|c|c|c|c|}
\hline & Year 1 & Year 2 & Year 3 & Year 4 & Year 5 \\
\hline Anticipated cash inflows & 53.000 & 53.000 & 53.000 & 53.000 & 53.000 \\
\hline Anticipated cash outflows & 20.000 & 20.000 & 20.000 & 20.000 & 20.000 \\
\hline Gross operating surplus & 33.000 & 33.000 & 33.000 & 33.000 & 33.000 \\
\hline Income tax & 16.500 & 16.500 & 16.500 & 16.500 & 16.500 \\
\hline Net operating surplus & 16.500 & 16.500 & 16.500 & 16.500 & 16.500 \\
\hline Tax savings from depreciation (T·A) & 10.000 & 10.000 & 10.000 & 10.000 & 10.000 \\
\hline Anticipated net cash flows & 26.500 & 26.500 & 26.500 & 26.500 & 26.500 \\
\hline
\end{tabular}

Depreciation $\left(\mathrm{A}_{\mathrm{i}}\right)=\frac{100.000}{5}=20.000$ lei, $\mathrm{i}=\overline{1,5}$

$\mathrm{NPV}_{\text {without inf lation }}=\sum_{\mathrm{i}=1}^{5} \frac{26.500}{(1+0,09)^{\mathrm{i}}}-100.000=26.500 \cdot 3,8897-100.000=$

$103.077-100.000=3.077$ lei $>0$ and the project is accepted.

In Table 6, the estimates of anticipated net cash flows include the effects of inflation.

Table no. 6

Expected net cash flows taking into account the effects of inflation (T=50\%)

\begin{tabular}{|l|c|c|c|c|c|}
\hline \multicolumn{1}{|c|}{ Indicators (lei) } & Year 1 & Year 2 & Year 3 & Year 4 & Year 5 \\
\hline Anticipated cash inflows & 56.180 & 59.551 & 63.124 & 66.912 & 70.927 \\
\hline Anticipated cash outflows & 21.400 & 22.898 & 24.501 & 26.216 & 28.051 \\
\hline Gross operating surplus & 34.780 & 36.653 & 38.623 & 40.696 & 42.876 \\
\hline Income tax & 17.390 & 18.327 & 19.312 & 20.348 & 21.438 \\
\hline Net operating surplus & 17.390 & 18.327 & 19.312 & 20.348 & 21.438 \\
\hline Tax savings from depreciation (T·A) & 10.000 & 10.000 & 10.000 & 10.000 & 10.000 \\
\hline Anticipated net cash flows & 27.390 & 28.327 & 29.312 & 30.348 & 31.438 \\
\hline
\end{tabular}

NPV calculation is the following: 
$\mathrm{NPV}_{\text {with inf lation }}=\frac{27.390}{1+0,1554}+\frac{28.327}{(1+0,1554)^{2}}+\frac{29.312}{(1+0,1554)^{3}}+\frac{30.348}{(1+0,1554)^{4}}+\frac{31.438}{(1+0,1554)^{5}}-100.000=$

$27.390 \cdot 0,865+28.327 \cdot 0,748+29.312 \cdot 0,647+30.348 \cdot 0,559+31.438 \cdot 0,484-100.000=$

$23.692+21.889+18.965+16.965+15.216-100.000=96.727-100.000=-3.273$ lei

So $\mathrm{NPV}_{\text {with inflation }}<0$ and the project will be rejected. In this example, the forces of inflation on cash out-flows was higher than on cash inflows.

\section{Conclusions}

Of those listed above, we noticed that if we do not take into account the effects of inflation can do an wrong analysis of capital budgeting. The project was supported when in reality has a rate of return below the cost of capital, caused by unequal impact of inflation on cash inflows and cash out flows. As a consequence, in our example, the NPV project was negative (for $\mathrm{T}=50 \%$ ). But this is not a general rule, that is making the necessary adjustments due to inflation is not always necessarily in a negative NPV project (see tables 1, 2.3 and no.4). Clearly, the results are more accurate by taking into account the effects of inflation.

\section{References:}

1. Arnold, G., (2008), Corporate financial management, Fourth Edition, Prentice Hall Publishing House, London, England

2. Berceanu, D., (2006), The financial decisions of the firm, Second Edition, Universitaria Publishing House, Craiova

3. Brealey, R., Myers, S., Marcus A., (2007), Fundamentals of corporate finance, Fifth Edition, McGraw Hill Publishing House, New York, United States of America

4. Brigham, E., Daves, P., (2004), Intermediate financial management, Eighth Edition, Thomson South Western Publishing House, New York, United States of America

5. Ross, S., Westerfield, R., Jafee, J., Jordan, Bradford, (2008), Modern financial management, Eighth Edition, McGraw Hill Publishing House, New York, United States of America 